\title{
免震鉛ダンパー接合用アンカーボルトの引抜き挙動に関する基礎実験 PULL-OUT TEST OF ANCHOR BOLT FOR FASTENING LEAD DAMPER TO CONCRETE FOUNDATION
}

\author{
浅田勇人*, 吉敷祥一**, 和田章*** \\ Hayato ASADA, Shoichi KISHIKI and Akira WADA
}

\begin{abstract}
Pull-out tests on anchor bolts for fastening lead damper to concrete foundation were conducted to evaluate factors affecting pull-out behavior of anchor bolts. The main parameters were type of anchor bolt commonly used for anchorage of lead damper and layout of reinforcements around anchor bolt. The following results were obtained : (1) Vertical reinforcements arranged around anchor bolt contribute to increase in concrete breakout strength. (2) For long nut type anchor bolt, long nut length covered anchor bolt must be treated with enough care to avoid slipping anchor bolt. Because slipping failure lead to decrease in tensile strength and increase in pull-out displacement at failure. (3) The slope of the concrete cone was much flatter than 45 degree assuming in design procedure, regardless of the embedment depth, anchor type and reinforcement pattern. (4) Based on test results, simple concrete failure model was proposed. Using this model, effective radius of projected area were assessed $0.81 l_{e}$ $0.96 l_{e}$. These values were close to effective radius $1.0 l_{e}$ in existing design formula according to AIJ.
\end{abstract}

Keywords: Base-isolated structure, Lead damper, Connection, Pull-out test, Concrete cone failure, Pull-out behavior 免震構造，鉛ダンパー，接合部，引抜き実験，コーン状破壊，引抜き挙動

\section{1. 序}

\section{1 研究背景}

免震構造は，上部構造と基礎との間に，鋁直方向に十分剛で強 度をもち，水平方向に柔なアイソレータを設置し，同時に地震入力 エネルギーを吸収するためのダンパーを設置することによって，地 震時の建築物に生じる大きな加速度を低減する構造である。このよ うなアイソレータ及びダンパーはその要求される力学性能を十分に 発揮させることだけでなく，上部構造や基礎との接合部が十分な強 度と剛性をもつことが必須である。例えば，図 1 に示すような鉛ダ ンパーを基礎へ定着寸るために用いられるアンカーボルトには，地 震時の水平力による曲げモーメントとせん断力に加え，ダンパーの 大変形時にも免震層の階高がほぼ一定に保たれるという幾何学的な 拘束条件によって，大きな引抜き力が作用する ${ }^{1)}$ ．福岡西方沖地震 では，この引抜き力によってアンカーボルトの脆性破壞（コーン状 破壊）が生じた。この破壞は，ダンパーの大変形時に生じる鉛直軸 力についての配慮が足りなかったことに加え，アンカーボルト周辺 の配筋方法が未検討であったことが原因として考えられる．近年で は超高層建築物にも免震構造が採用されるようになり，免震部材の 大型化や高面圧化が進んでいる，積層ゴムアイソレータについても レベル 2 地震動において $1 \mathrm{~N} / \mathrm{mm}^{2}$ の引張が生じることもあり, アン カーボルトには引抜き力に対する配慮が必要である.

引抜き力を受ける免震部材接合用アンカーボルトのコンクリート

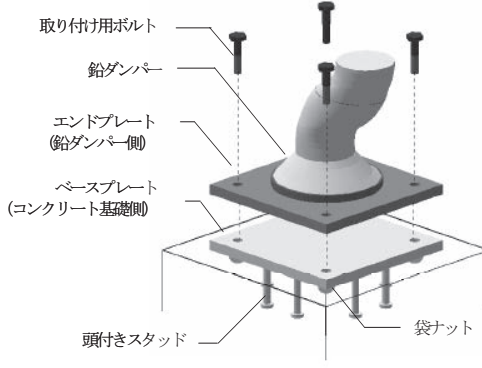

(a) スタッド形式

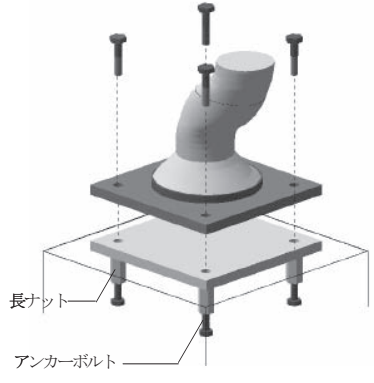

(b) 長ナット形式

図1 鉛ダンパーの定着形式

への定着に関する設計は, 日本建築学会「各種合成構造設計指針・ 同解説 1985」に準拠して行われている. 本論文で対象とする免震 部材接合用アンカーボルトは先付けアンカーボルトに分類され，ア ンカーボルト頭部での支圧抵抗と軸径の強度が十分に高い場合, 引 抜き耐力はコーン状破壊によって決定づけられる。この先付けアン カーボルトのコーン状破壊耐力に関する研究例えば 3) 7) はこれまで 数多く行われている. 一方, 免震部材接合用アンカーボルトに関し ては，広瀬ら ${ }^{8)}$ が引抜き実験を行い，コーン状破壊耐力に関して 検証を行うとともに，アンカーボルト周辺に付加的に加えた縦方向 鉄筋の補強効果について検討をおこなっているが，現状では免震部 材接合用アンカーボルトの引抜き挙動に関する研究は僅少である.
* 東京工業大学大学院

大学院生 $\cdot$ JSPS 特別研究員 $\cdot$ 修士 (工学)

** 東京工業大学建築物理研究センター 助教・博士 (工学)

*** 東京工業大学建築物理研究センター 教授. 工博
Graduate Student, JSPS Fellow, Tokyo Institute of Technology, M. Eng.

Assist. Prof., SERC, Tokyo Institute of Technology, Dr. Eng.

Prof., SERC, Tokyo Institute of Technology, Dr. Eng. 


\section{2 免震部材接合部の定着方法}

ここで，鉛ダンパー接合部を例とし，免震部材を据え付けるベー スプレートの定着形式と施工方法について述べる. 免震層には, 図 2 に示寸ような階高と免震部材の大きさに応じた鉄筋コンクリート基 礎梁からの立上部が設けられ，免震部材はこの立上部にアンカーさ れたベースプレートにボルト等で固定する.このベースプレートの 定着方法は, 図 1 に示すとおりにアンカーボルトの種類と免震部材 の接合方法によって 2 つの定着形式に分類できる. 図 1-(a) は頭付 きスタッドを定着に用いる方法である（以下，スタッド形式）。ス タッド形式では立上部上のベースプレートに定着用の頭付きスタッ ドと，免震部材のエンドプレートを接合するための袋ナットが別に 溶接される．従って頭付きスタッドと袋ナットの間に偏心距離が生 じ，免震部材から伝達される引抜き力は袋ナットからプレートの面 外曲げを介してアンカーボルトに伝わるため, てこ反力の影響によ り引抜き耐力が低下寸る問題がある ${ }^{9)}$. 図 1-(b) は，六角ボルトあ るいはそれに相当するアンカーボルトを長ナットに挿入して用いる 方法（以下，長ナット形式）である，長ナット形式では，立上部に 据え付けるベースプレートに長ナットをあらかじめ溶接する。この 長ナットがアンカーボルトと，取付用ボルトを繋ぐ接合部としての 役割を果たす。そのため長ナットには取付用ボルトとアンカーボル トの双方のねじインサート長さが必要となり，アンカーボルトの埋 込み長さに対して長ナットの被覆が大きくなり易い。 また，アンカ 一ボルトを長ナットに固定するためにロックナットを取り付ける場 合には，さらにナットによるアンカーボルト軸部の被覆長さが増え る. 従って, 長ナット形式では長ナットによるアンカーボルト軸部 の被覆長さによっては, ボル卜頭部での十分な支圧抵抗が行われず, 耐力や剛性を十分に確保できないというおそれがある。

\section{3 免震部材設置用ベースプレートの施工方法}

次いで，立上部上面に設置するベースプレートの施工方法につい て述べる。このベースプレートを定着するためのアンカーボルトは 免震部材に生じた軸力やせん断力を確実に基礎部へと伝達しなけれ ばならず，ベースプレートの施工に当たっては，ベースプレート下 部に密実にコンクリートを充填させることが重要となる。そこで図 3 に示寸グラウト充填工法と打ち込み工法が多く用いられる ${ }^{10)}$. 前 者は先行して打設した立上部とベースプレート間に $30 ２ 00 \mathrm{~mm}$ 程 度の隙間を残し，無収縮モルタルをその隙間に圧入する方法である. この場合, 基礎梁に定着された八カマ筋が先行打設コンクリート内 に配筋され，さらにグラウト分の被りが付加されるため，アンカー ボルト周辺に十分な配筋が行われない可能性がある。後者は高流動 コンクリートを使用し，ベースプレート中央からコンクリートを流 し込み, 立上部からベースプレートまで一度に打設する方法である. この工法では立上部が一度に打設されるため一体性を保つことがで きるが，立上部のコンクリートを打設する前に立上筋をあらかじめ 基礎梁内に定着するため，鉄筋の上下位置を調整することができな い．また，ベースプレートを所定の高さに設置するためにレベル調 整が行われるため, 立上部上面の被り厚が設計で想定した位置より 下がる可能性がある。さらに，アンカーボルト近傍に鉄筋が密に配 置されるとベースプレートの設置及びレベル調整が困難になるた め，ベースプレート中央の配筋を避けて，基礎からは縦方向の鉄筋 （立上筋）のみを立ち上げておき，ベースプレート設置後に横方向

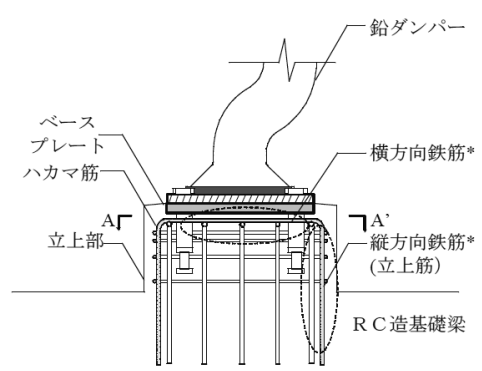

(a) RC造立上部の形状と配筋例

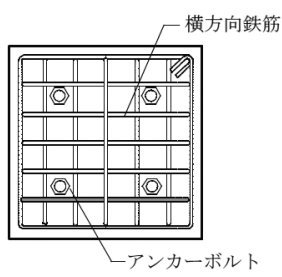

(b) A-A'断面図

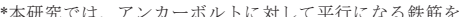
縦方向鉄筋，直交する鉄筋を横方向鉄筋とそれぞれ称す。

図2 立上部の配筋状況

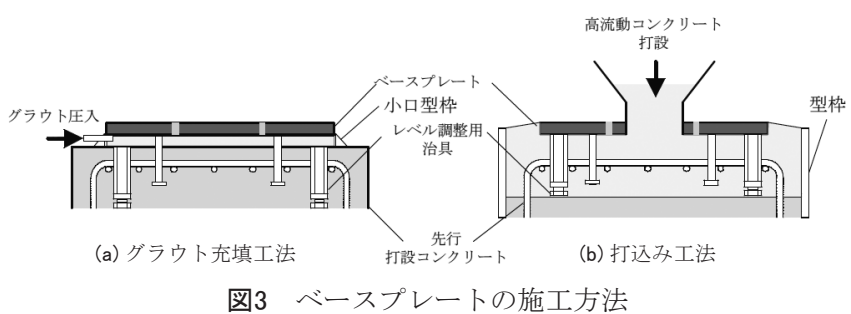

鉄筋を立上筋に接合するなど，アンカーボルト周辺の配筋が不十分 になる可能性がある。

\section{4 研究目的}

本論文では以上のような鉛ダンパー接合用アンカーボルトの形状 と施工方法の問題点に着目し，アンカーボルトの引抜き挙動に及ぼ す長ナット形式アンカーボルトの形状及びアンカーボルト周辺に配 筋した鉄筋の影響を把握するため，アンカーボルトの引抜き実験を 行う.

\section{2. 実験概要}

\section{1 試験体と試験パラメータ}

試験体は鉛ダンパーの接合部に用いられるアンカーボルト単体 と，定着する鉄筋コンクリート立上部を模したコンクリート母材か らなる。試験体の形状と定着用鉄筋の配筋状況を図 4 に示寸。全試 験体でコンクリート母材の寸法は同一であり，平面形状が $500 \mathrm{~mm}$ × $500 \mathrm{~mm}$ ，高さ $600 \mathrm{~mm}$ の直方体である.アンカーボルトは母材中 央部に設置し、縁あき距離はアンカーボルトの埋込み長さの 2 倍以 上をとり，コーン状破壊耐力への縁あき距離の影響を無視できるほ ど十分に確保してある。試験体に使用した鉄筋およびコンクリート の材料試験結果を表 1 , 表 2 に示す。 また, 表 2 下にアンカーボル 卜の機械的性質を示す。全試験体とも同一のフレッシュコンクリー 卜を使用して製作した。コンクリートは打設後一週間を蒸気養生と し, その後, 気中養生とした. アンカーボルトの形状を図 5 に示す. 本実験では図 1 に示した長ナット形式とスタッド形式に対応する 2 種類のアンカーボルトを用いた. 長ナット形式のアンカーボルトは, 長ナットを装着した全礼じ六角ボルト（M24 × 200）とした。スタ ッド形式のアンカーボルトは頭付きスタッドであり， $50 \mathrm{~mm}$ 角の直 方体のカプラーにあらかじめスタッド溶接してある.

本研究では, 長ナット形式アンカーボルトの形状とアンカーボル 卜周辺の鉄筋の配筋状況がアンカーボルトの引抜き挙動に及ぼす影 響を把握するため，これらを主な試験パラメータとした。試験体は 
この主たる試験パラメータによって $\mathrm{N}$ シリーズと $\mathrm{R}$ シリーズの 2 つの試験シリーズに大別できる。試験体一覧を表 3 に示す。試験体 名称の定義を図 6 に示す.

\section{【Nシリーズ】}

$\mathrm{N}$ シリーズでは, 長ナット形式アンカーボルトの長ナット被覆長 さ $l_{n}$ を主たるパラメータとし，長ナットによる被覆がアンカーボ ルトの引抜き挙動に及ぼす影響を考察する. 長ナット形式アンカー ボルトはいずれの試験体においても埋込み長さ $l_{e}$ が $120 \mathrm{~mm}$ になる ようにコンクリートに埋設してあり, 長ナット被覆長さ $l_{n}$ は 50,80 , $100 \mathrm{~mm}$ の計 3 種類を用意した。また, 長ナットを装着していない 無垢の全礼じ六角ボルトをそのままアンカーボルトとして用いた試 験体も用意した。さらに，ねじ部の付着の有無による影響を検討す るために，ボルトのねじ部をビニールテープで巻いた後にグリース を塗布して付着を絶縁したアンカーボルトをもつ試験体（UB）も 用意した. なお，このシリーズでは図 4 に示すように母材下面から

表1 コンクリートの材料試験結果

\begin{tabular}{|c|c|c|c|}
\hline & $\begin{array}{l}\text { 割裂強度 } \\
{\left[\mathrm{N} / \mathrm{mm}^{2}\right]}\end{array}$ & $\begin{array}{c}\text { 圧縮強度 } \\
{\left[\mathrm{N} / \mathrm{mm}^{2}\right]}\end{array}$ & $\begin{array}{c}\text { ヤング係数 } \\
{\left[\mathrm{N} / \mathrm{mm}^{2}\right]}\end{array}$ \\
\hline Nシリーズ & 2.34 & 27.80 & $2.35 \times 10^{4}$ \\
\hline Rシリーズ & 2.36 & 29.30 & $2.66 \times 10^{4}$ \\
\hline
\end{tabular}

表2 鉄筋の材料試験結果

\begin{tabular}{c|c|c|c}
\hline & $\begin{array}{c}\text { 降伏点 } \\
{\left[\mathrm{N} / \mathrm{mm}^{2}\right]}\end{array}$ & $\begin{array}{c}\text { 引張強さ } \\
{\left[\mathrm{N} / \mathrm{mm}^{2}\right]}\end{array}$ & $\begin{array}{c}\text { ヤング係数 } \\
{\left[\mathrm{N} / \mathrm{mm}^{2}\right]}\end{array}$ \\
\hline \hline D6(SD295A) & 370 & 552 & $1.87 \times 10^{5}$ \\
\hline D13(SD295A) & 368 & 521 & $1.73 \times 10^{5}$ \\
\hline
\end{tabular}

頭付きスタッドは, 降伏強度 $407 \mathrm{~N} / \mathrm{mm}^{2}$ 引張強さ $457 \mathrm{~N} / \mathrm{mm}^{2}$ である。 全衩じ六角ボルト（S45C）は強度区分 8.8T の高強度ボルトである.
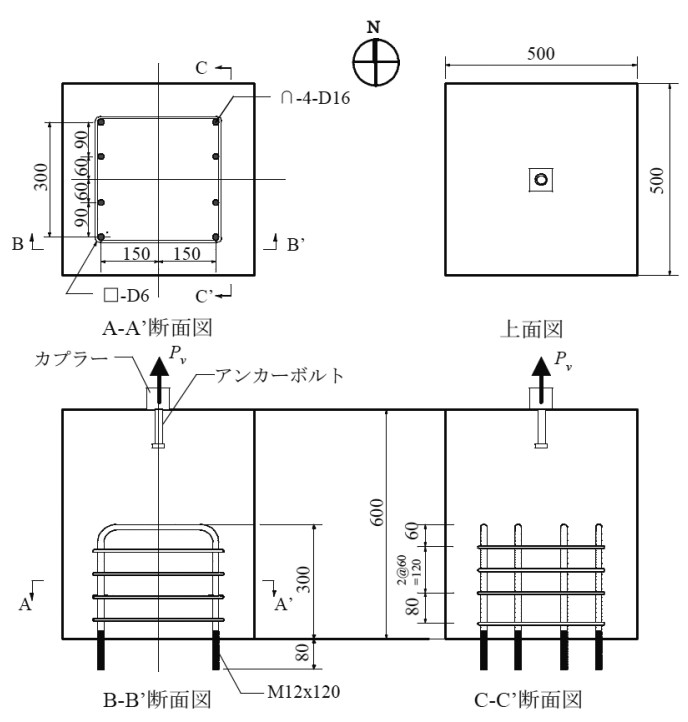

図4 試験体の形状と配筋詳細（S120）

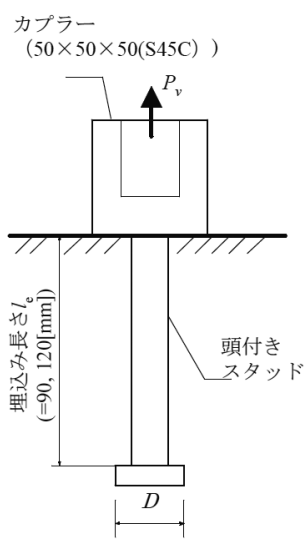

(a) スタッド形式

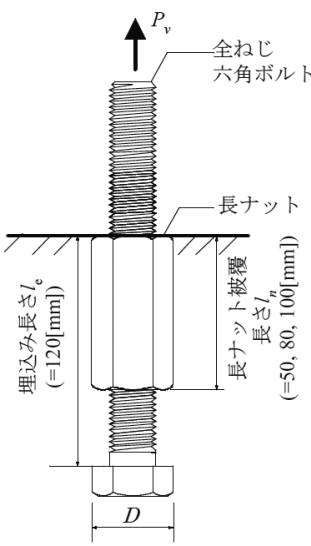

(b) 長ナット形式
図5 アンカーボルトの形状

表3 試験体一覧

\begin{tabular}{|c|c|c|c|c|c|c|c|c|}
\hline \multirow[b]{2}{*}{ シリーズ } & \multirow[b]{2}{*}{ 試験体名 } & \multirow{2}{*}{$\begin{array}{c}\text { アンカー } \\
\text { ボルトの } \\
\text { 種類 } \\
\end{array}$} & \multirow{2}{*}{$\begin{array}{l}\text { 埋込み } \\
\text { 長さ } \\
l_{e}[\mathrm{~mm}] \\
\end{array}$} & \multirow[b]{2}{*}{$\begin{array}{l}\text { 頭部外径 } \\
D[\mathrm{~mm}]\end{array}$} & \multirow{2}{*}{$\begin{array}{c}\text { 長ナット } \\
\text { 被覆長さ } \\
l_{n}[\mathrm{~mm}] \\
\end{array}$} & \multicolumn{3}{|c|}{ アンカーボルト周辺の配筋状況 } \\
\hline & & & & & & $\begin{array}{c}\text { かぶり厚さ3* } \\
{[\mathrm{mm}]}\end{array}$ & $\begin{array}{c}\text { 縦方向鉄筋 } \\
\text { [本数 }]\end{array}$ & $\begin{array}{c}\text { 横方向鉄筋 } \\
\text { [本数 }]\end{array}$ \\
\hline \multirow{6}{*}{$\mathrm{N}$} & N120 & \multirow{6}{*}{$\begin{array}{c}\text { 六角全ねじ } \\
\text { ボルト } \\
(\mathrm{F} 8.8 \mathrm{~T})\end{array}$} & \multirow{6}{*}{120} & \multirow{6}{*}{$40^{2^{*}}$} & 0 & \multirow{6}{*}{ - } & \multirow{6}{*}{ - } & \multirow{6}{*}{-} \\
\hline & N120(50) & & & & 50 & & & \\
\hline & $\mathrm{N} 120(50) \mathrm{UB}^{1 *}$ & & & & 50 & & & \\
\hline & $\mathrm{N} 120(80)$ & & & & \multirow{2}{*}{80} & & & \\
\hline & $\mathrm{N} 120(80) \mathrm{UB}^{1 *}$ & & & & & & & \\
\hline & N120(100) & & & & 100 & & & \\
\hline \multirow{10}{*}{$\mathrm{R}$} & S90 & \multirow{10}{*}{$\begin{array}{c}\text { 頭付きスタッド } \\
\phi 19\end{array}$} & 90 & \multirow{10}{*}{32} & \multirow{10}{*}{ - } & \multirow{2}{*}{ - } & \multirow{2}{*}{-} & \multirow{2}{*}{ - } \\
\hline & S120 & & \multirow{9}{*}{120} & & & & & \\
\hline & $2 \mathrm{H} 30$ & & & & & \multirow{2}{*}{30} & \multirow{4}{*}{ - } & 2 \\
\hline & $4 \mathrm{H} 30$ & & & & & & & \multirow{3}{*}{4} \\
\hline & $4 \mathrm{H} 60$ & & & & & 60 & & \\
\hline & $4 \mathrm{H} 120$ & & & & & 120 & & \\
\hline & $4 \mathrm{~V} 30$ & & & & & 30 & \multirow{2}{*}{4} & \multirow{2}{*}{-} \\
\hline & $4 \mathrm{~V} 60$ & & & & & 60 & & \\
\hline & $2 \mathrm{HV} 30$ & & & & & \multirow{2}{*}{30} & 2 & 2 \\
\hline & $4 \mathrm{HV} 30$ & & & & & & 4 & 4 \\
\hline
\end{tabular}

Nシリーズ(一部のRシリーズを含む)

N 120 (50)

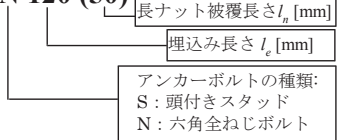
Rシリーズの試験体名称

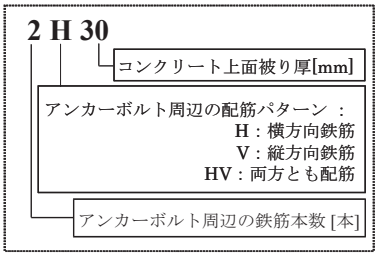

図6 試験体名称

* :アンカーボルトのねじ部の付着をビニールテープとグリースで絶縁してある。

2*: 六角ボルトの場合は頭部の最外径である。

$3^{*}:$ 横方向鉄筋の上面からの被り厚 
$\stackrel{x}{\oplus}$

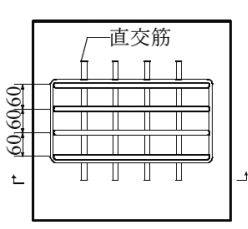

横方向鉄筋\% D13

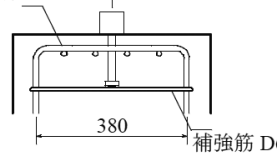

(a) 横方向鉄筋のみ
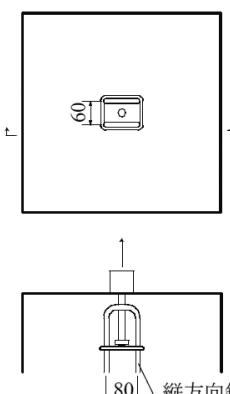

80. 縦方向龂
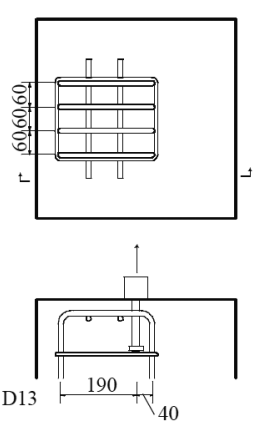

(c) 縦・横方向鉄筋両方 $※ 2$ 本の場合は, 中央に近い 2 本のみを配筋する

図7 アンカーボルト周辺の配筋方法
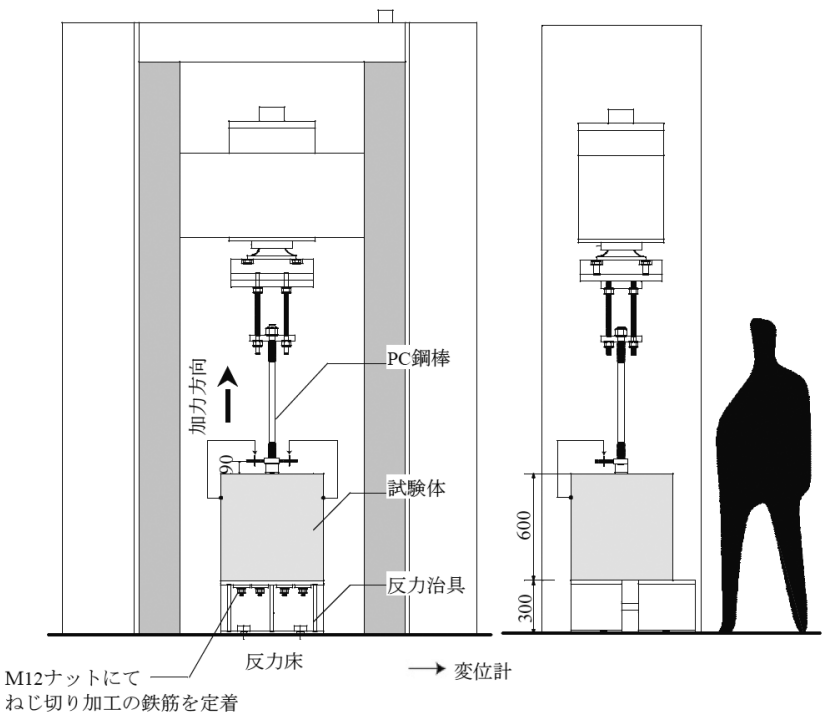

(a) 東側立面図 (b) 南側立面図

図8 試験体セットアップ

$300 \mathrm{~mm}$ 以上の位置には鉄筋を一切配筋していない． N シリーズは ，以上のパラメータを組み合わせた計 6 体で構成される.

\section{【Rシリーズ】}

$\mathrm{R}$ シリーズでは，アンカーボルトの周辺に存在する鉄筋の配筋方 法を主たるパラメータとし, 配筋方法の違いがアンカーボルトの引 抜き挙動に及ぼす影響を考察する， R シリーズの試験体は， $\phi 19$ × 130 の頭付きスタッドをアンカーボルトとして使用している．R シリーズの試験体の配筋方法を図 7 に示す。なお，アンカーボルト 周辺の鉄筋はすべて下面から $50 \mathrm{~mm}$ の位置まで伸ばし，折り曲げ 角度を $180^{\circ}$ とした定着端を施して十分な定着を行った. アンカー ボルト周辺の配筋方法は，立上部におけるアンカーボルト周辺の配 筋状況を反映して，アンカーボルト周辺に横方向鉄筋のみを配筋し たもの (H)，縦方向鉄筋のみを配筋したもの（V)，縦・横方向鉄

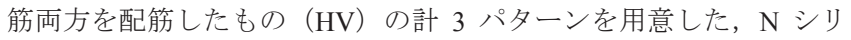
ーズの試験体と同様にアンカーボルト周辺に一切配筋しない試験体 も用意した。また，アンカーボルトと周辺鉄筋の上下位置関係の影 響を検討するため，コンクリート母材上面からの鉄筋の被り厚を変 動要因とし，30，60，120mm の3 種類を用意した。さらに，アン カーボルト周辺に鉄筋のない試験体で，アンカーボルトの埋込み長

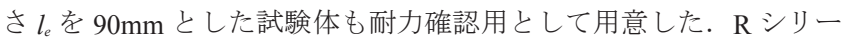
ズは以上のパラメータを組み合わせた計 10 体の試験体で構成され る.

\section{2 載荷方法と計測計画}

セットアップを図 8 に示す。立上部上に設置した免震部材からア ンカーボルトへ伝わる引張力が立上部下面から基礎梁へと流れると いう境界条件を反映して，試験体下部をコンクリート母材下面から 突出した定着用鉄筋にねじ加工を施し鉄骨治具にナットで固定し た。また，上部はカプラーを介してアンカーボルトと載荷装置側 PC 鋼棒を接続して載荷装置に連結し上下から引張力が作用するように 試験体を設置した，実験は単調引張力を加えて，試験体を破壊に至 らしめた。

試験体に作用する引抜き荷重 $P_{v}$ は載荷装置に装備されたロード
セルより測定した．抜け出し変位。 $\delta$ はアンカーボルトのコンクリ 一下母材に対する相対鉛直変位から，測定区間内の治具の弾性変形 分を差し引いた值と定義し，アンカーボルトの伸びを含んだもので ある。計測にはばね式接触型変位計を使用し, 計測ターゲットはコ ンクリート上面から $90 \mathrm{~mm}$ の位置に設置した。なお，相対鉛直変 位は $3 つ の$ 変位計で計測を行い, その平均值を用いた.

\section{3. 実験結果}

\section{1 最大耐力と破壊性状}

実験結果一覽を表 4 に示す. 表中のコーン状破壊耐力の計算值 ${ }_{c a l} P_{u}$ は各種合成構造設計指針・同解説に基づき式 (1) によって算 出した。式中のコンクリート圧縮強度は材料試験結果を適用した。

$$
{ }_{\text {cal. }} P_{v}=0.31 \sqrt{\sigma_{B}} \cdot A_{c}
$$

ここで $A_{c}$ : 有効水平投影面積 $\left(=\pi l_{e} \cdot\left(l_{e}+D\right)\right)$

$$
\sigma_{B} \text { : コンクリートの圧縮強度 }\left[\mathrm{N} / \mathrm{mm}^{2}\right]
$$

本実験で確認できた破壊形式の模式図を図 10 に示す。いずれの 試験体もコーン状破壊が先行するように設計したが，実験ではコー ン状破壊（C），アンカーボルトのスリップ破壊（S），軸部の破断 （F）の 3 種類の破壊形式が確認できた。本実験で確認できたコー ン状破壊の一例として S120 の破壊面を図 11 に示す。破壊面は試 験体を破壊に至らしめた後, 破損したコンクリート片を除去し, 破 壊面内を $25 \mathrm{~mm}$ ピッチでレーザー変位計を用いて計測したもので ある。破壊面に対する定着長さ，アンカー形式，及び鉄筋の影響に ついて検討するため, 破壊面の断面形状を比較したものを図 12 に 示す。比較した破壊面は図 11 中の A-A'断面である. N, R シリ ーズの試験体のうちコーン状破壊に至った試験体の破壊面は図 11 に示すような概ね軸対称形の円錐状である。いずれも設計で想定さ れているコーン状破壊面 ${ }^{2)}$ より幅に緩やかになっていることがわ かる．特に無筋の試験体についてはその傾向が顕著である.

次いで各シリーズの破壊状況と耐力について検討する。 N シリー ズの試験体はN120（100）を除くいずれの試験体もコーン状破壊に至 
った. 図 12-(a), 図 12-(b)では, スタッド形式の試験体と比較し ても大きな差異がみられないことから破壊面の形状にアンカーボル トの形状が与える影響は少ないと言える。 また, スタッド形式にお ける埋込み長さの影響もないことが確認できる。一方，アンカーボ ルトの軸部の 80 \%が長ナットによって被覆されている N120（100） については写真 1 に示すとおりコンクリート母材からアンカーボル トが滑り抜ける破壊（スリップ破壞）に至った．Nシリーズの試験 体の最大耐力の実験值とコーン状破壊耐力の計算值を比較したもの を図 13-(a) に示す，横軸を長ナット被覆率 [\%]とし，長ナットの 被覆が最大耐力に与える影響を比較する。長ナット被覆率とは, 埋 込み長さ $l_{e}$ に対する長ナット被覆長さ $l_{n}$ の比率である. コーン状 破壊に至った N シリーズの試験体は，N120 についてはわずかに他 の試験体に比べて耐力が小さくなっているが，長ナットの長さ及び ネジ部の付着の有無にかかわらずコーン状破壊耐力の実験值と計算 值は良好に対応している。一方, 埋込み長さの 80 \% 程度が長ナッ 卜によって被覆してあるN120（100）は，頭部での十分な支圧抵抗が 行われなかったために, コーン状破壊ではなくアンカーボルトのス リップ破壊に至っており，耐力が低下している．従って長ナット被 覆率の増大に伴う破壊モードの遷移及び耐力低下に十分配慮しなけ ればならない。

$\mathrm{R}$ シリーズのうち, アンカーボルト周辺に横方向鉄筋のみ配筋し た試験体はいずれもコーン状破壊に至った。破壊面の形状は無筋試 験体に比べて, やや不整形な形状となりアンカーボルト頭部近傍の 破壊面角度も無筋試験体と比較するとやや大きくなっている．これ は後に詳述するがアンカーボルト頭部による支圧抵抗と折り曲げ定 着近傍の鉄筋がストラットを形成するような機構が生じたためであ ると考えられる. アンカーボルト周辺に縦方向鉄筋のみを配筋した 試験体はいずれもアンカーボルト軸部の破断によって最大耐力に至 った. アンカーボルト周辺に横方向鉄筋と縦方向鉄筋を両方配筋し た試験体では，縦方向鉄筋を 2 本のみ配筋した試験体はコーン状破 壊に至ったが，4 本配筋した試験体はアンカーボルトの軸部破断で 最大耐力に至った. アンカーボルト周辺に鉄筋を配筋した $\mathrm{R}$ シリ

表4 実験結果一覧

\begin{tabular}{|c|c|c|c|c|}
\hline 試験体名 & $\begin{array}{c}\exp P_{u}{ }^{{ }^{1 *}} \\
{[\mathrm{kN}]} \\
\end{array}$ & $\begin{array}{c}{ }_{\text {cal. }} P_{u}{ }^{2^{*}} \\
{[\mathrm{kN}]} \\
\end{array}$ & $\begin{array}{c}\text { 破壊 } \\
\text { モード } \\
\end{array}$ & $\exp P_{u} /{ }_{\text {cal. }} P_{u}$ \\
\hline N120 & 93.70 & \multirow{6}{*}{99.82} & $\mathrm{C}$ & 0.94 \\
\hline N120(50) & 99.26 & & $\mathrm{C}$ & 0.99 \\
\hline N120(50)UB & 103.73 & & $\mathrm{C}$ & 1.04 \\
\hline $\mathrm{N} 120(80)$ & 108.06 & & $\mathrm{C}$ & 1.08 \\
\hline N120(80)UB & 101.35 & & $\mathrm{C}$ & 1.02 \\
\hline N120(100) & 91.38 & & $\mathrm{~S}$ & 0.92 \\
\hline $\mathrm{S} 90$ & 75.46 & 57.90 & $\mathrm{C}$ & 1.30 \\
\hline S120 & 113.68 & 96.19 & $\mathrm{C}$ & 1.18 \\
\hline $2 \mathrm{H} 30$ & 115.83 & \multirow{8}{*}{96.19} & $\mathrm{C}$ & 1.20 \\
\hline $4 \mathrm{H} 30$ & 121.09 & & $\mathrm{C}$ & 1.26 \\
\hline $4 \mathrm{H} 60$ & 114.32 & & $\mathrm{C}$ & 1.19 \\
\hline $4 \mathrm{H} 120$ & 102.45 & & $\mathrm{C}$ & 1.07 \\
\hline $4 \mathrm{~V} 30$ & 132.41 & & $\mathrm{~F}$ & 1.38 \\
\hline $4 \mathrm{~V} 60$ & 129.79 & & $\mathrm{~F}$ & 1.35 \\
\hline $2 \mathrm{HV} 30$ & 128.38 & & $\mathrm{C}$ & 1.33 \\
\hline $4 \mathrm{HV} 30$ & 133.63 & & $\mathrm{~F}$ & 1.39 \\
\hline
\end{tabular}

2*:式(1) より算出したコーン状破壊の計算値

$3^{*}$ : C: コーン状破壞, S : スリップ破壊, F : アンカーボルトの軸部破断 (図10 参照)

ーズの試験体の最大耐力はいずれもコーン状破壊耐力の計算值を上 回る結果となっている. アンカーボルト周辺に横方向鉄筋のみを配 筋した試験体（H）のコーン状破壊耐力の実験值と計算值を比較し たものを図 13-(b)に示す. グラフの横軸は, 上面からの横方向鉄 筋の被り厚とした．横方向鉄筋の上面からの被り厚が大きくなるに つれて, 破壞耐力は低くなる傾向にあり, 被り厚が $120 \mathrm{~mm}$ である $4 \mathrm{H} 120$ は, 無筋試験体 S120 よりも最大耐力が $10 \%$ 程度低くなって いる.この試験体はアンカーボルトの埋込み長さと上面からの被り 厚が一致している試験体であり, 破壊面はおおよそ横方向鉄筋の上 面に沿って形成されている。この破壊状況から鉄筋が破壊面を助長 寸るように割り裂く効果が働き, 耐力が低下したと推察できる.

縦方向鉄筋を配筋した $4 \mathrm{~V} 30$ と $4 \mathrm{~V} 60$ については, 頭付きスタッ ドの軸部破断によって最大耐力に達しており，コーン状破壊耐力は 表中よりさらに大きくなった可能性がある. また, 縦方向鉄筋と横 方向鉄筋を両方とも配筋した試験体（HV）ではいずれも無筋試験 体に比べて耐力が大幅に上昇していることから, 縦方向鉄筋のアン カーボルトの引抜き抵抗に対する寄与が認められる.

\section{3 抜け出し性状}

\section{3. 1 長ナットによる影響}

長ナット形式アンカーボルトをもち, ねじ部の付着の有無をパラ メータとした試験体の引抜き荷重 $P_{v}$ 一抜け出し変位。 $\delta$ 関係を比較 したものを図 14 に示す. 図中には, コーン状破壊耐力の計算值と, コーン状破壊耐力計算值の $60 \%$ の值を短期許容荷重 ${ }^{2)}$ として併せ て示す．ねじ部の付着を絶縁した試験体において初期の荷重段階で わずかにスリップするような変形が生じているが，短期許容荷重以 下の範囲では両者の大きな差異は見られない。一方, 短期許容荷重 以降の荷重下では付着を絶縁した試験体の抜け出し変位が急増して おり, 最大耐力時には付着がある試験体に対して 2 倍以上の変形が 生じている.このことからアンカーボルトの秝じ部の長さが抜け出 し性状に大きく影響していると言える. 長ナット被覆率と最大耐力 時の抜け出し変位、 $\delta_{\max }$ の関係を図 15 に示す、コーン状破壊に至っ た試験体については, 最大耐力時の抜け出し変位と長ナット長さは 比例関係にあり, 長ナットによる被覆はアンカーボルトの付着の損

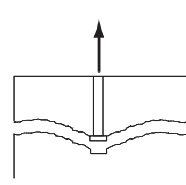

(a) コーン状破壊

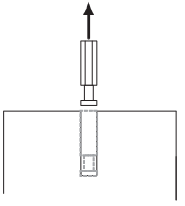

(b) スリップ破壞

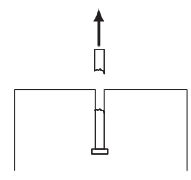

(c) アンカーボルトの軸部破断

図10 破壊モードの模式図

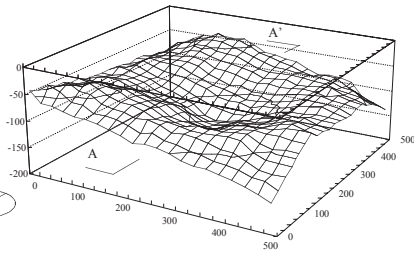

図11 コーン状破壊面の一例（S120）

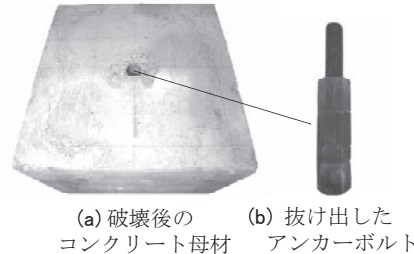

写真
コンクリート母材 アンカーボルト

真1 スリップ破壊

(N120(100)) 


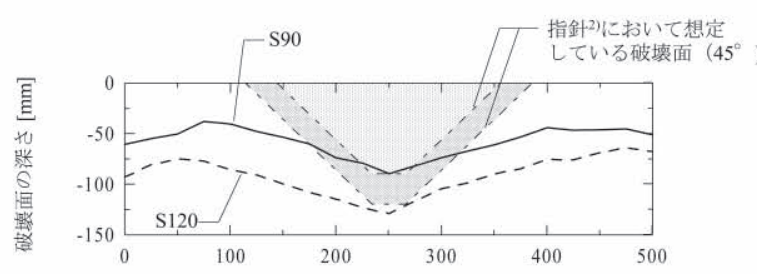

(a) アンカーボルトの長さによる影響

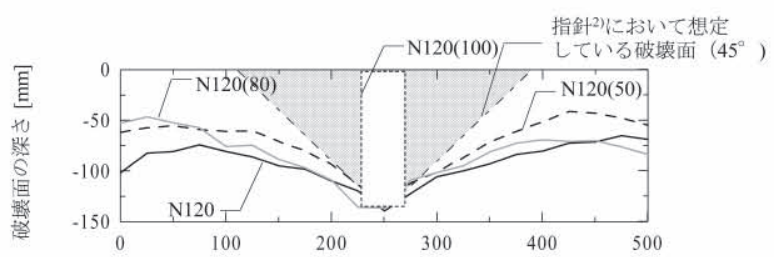

(b) 長ナットの長さによる影響
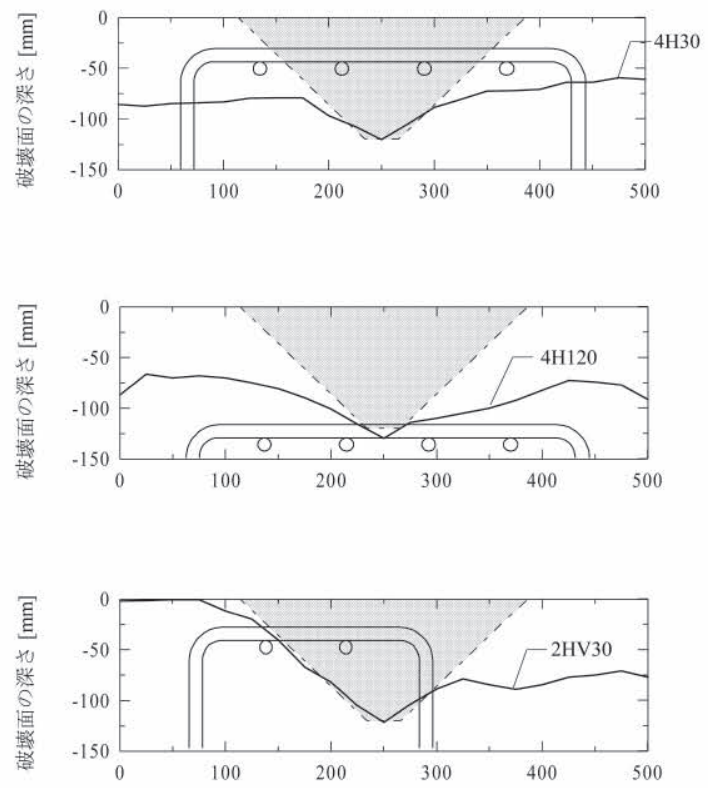

(c) 鉄筋の影響

図12 破壊面 $\mathrm{A}-\mathrm{A}^{\prime}$ 断面図

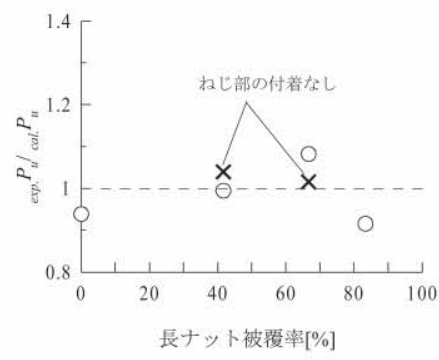

（a）長ナットによる被覆の影響

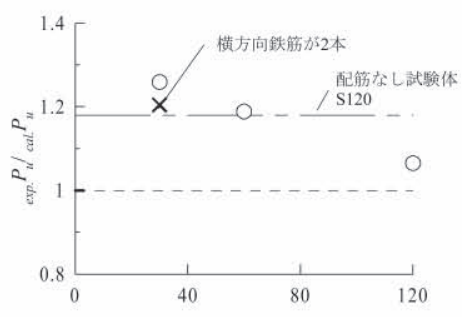

コンクリート母材上面からの被り厚[mm:]

(b) 横方向鉄筋の

上面からの被り厚の影響

図13 最大耐力とコーン状破壊耐力の計算值の比較

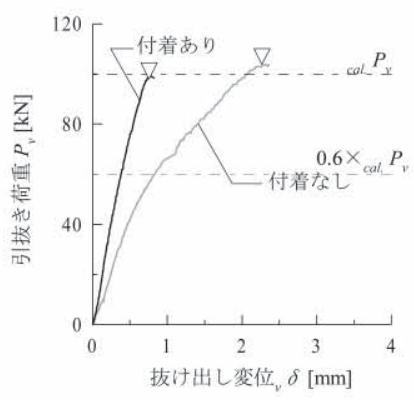

(a) N120(50)とN120(50)UB

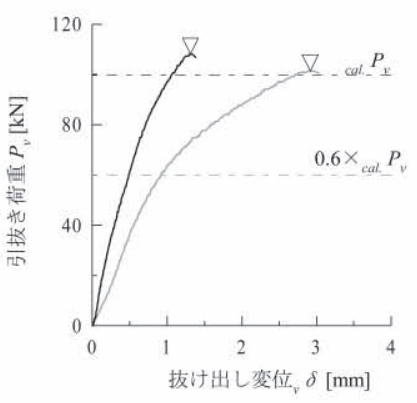

(b) N120(80)と N120(80)UB

図14 $P_{v}-\delta$ 関係（長ナット長さの違いによる影響）

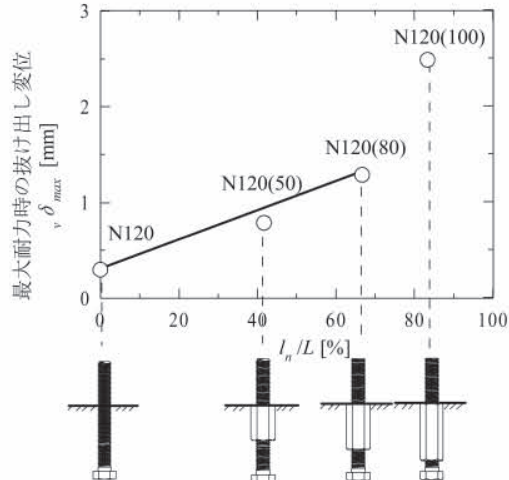

図15 最大耐力時の抜け出し変位

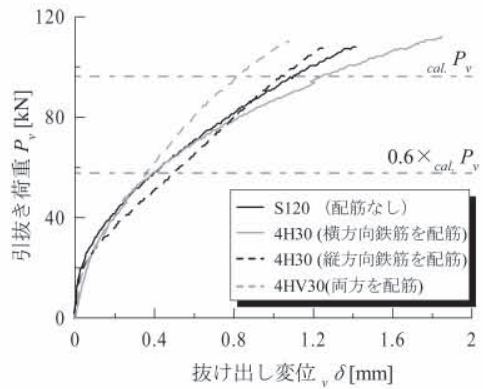

図16 $P_{v-v} \delta$ 関係

(鉄筋の有無，配筋方法による影響)
失として解釈できる。一方，長ナットの被覆率が 80 \%程度になる と破壊モードがコーン状破壊からスリップ破壊に転じ，最大耐力時 の抜け出し変位は大幅に大きくなる．また，この試験体はコーン状 破壞に至った長ナット形式の他の試験体に比べて耐力が低下してい ることから, 長ナット被覆率には十分注意する必要があると言える.

\section{3. 2 アンカーボルト周辺の鉄筋による影響}

アンカーボルト周辺に鉄筋を配筋した試験体と無筋試験体 S120 の引抜き荷重 $P_{v}$-抜け出し変位。 $\delta$ 関係を図 16 に示す、いずれの試 験体も最大耐力以前に頭付きスタッドの軸部が降伏したため，それ 以前までを示す。初期剛性はほぼ全試験体で一致しておりコンクリ 一トの損傷が少ない場合は，鉄筋の影響がないことが確認できる. 配筋方法の違いによる抜け出し挙動を比較すると, 全体の傾向とし て縦方向鉄筋を配筋した試験体のほうが，頭付きスタッドの弾性限 の範囲ではあるが，コンクリートの損傷に伴う非線形な抜け出し挙 動においてわずかに剛性が高くなる傾向にある。しかし，横方向鉄
筋のみを配筋した試験体との差異は少なく, アンカーボルト周辺の 鉄筋の存在あるいは配筋の違いが，アンカーボルトの抜け出し性状 に与える影響はほとんどないと言える。ただし, 破壞以前にアンカ 一ボルトが降伏したため，コーン状破壊に至るまでの鉄筋の有無， 配筋方法が抜け出し挙動に及ぼす影響については更なる検討が必要 である。

\section{4 鉄筋の耐力への寄与 \\ 3. 4. 1 横方向鉄筋の影響}

アンカーボルト周辺に横方向鉄筋のみを配筋した $4 \mathrm{H} 30$ と $4 \mathrm{H} 60$ の，最大耐力時における鉄筋に生じた曲げモーメント $M$ と軸力 $N$ の分布を図 17-(a)，（b)にそれぞれ示す．曲げモーメントは鉄筋に 貼付した歪ゲージより平面保持を仮定して算出した. 横方向鉄筋の ゲージ貼付位置を図 17-(c)に示す. 両試験体とも横方向鉄筋に生 じた曲げモーメントと軸力が小さいことが確認できる，上面の被り 厚が 30mm である $4 \mathrm{H} 30$ は, 無配筋の S120 に比べてコーン状破壊 
耐力が上昇している試験体である。この試験体の最大耐力時に横方 向鉄筋に生じた歪ゲージ貼付区間内の最大せん断力は $0.09 \mathrm{kN}$ と小 さく, 横方向鉄筋の引抜き抵抗に対する寄与は小さいことが確認で きる。一方，アンカーボルトの軸心から水平距離で $1.5 l_{e}$ 以上離 れている縦方向鉄筋に生じた軸力 $N$ は最大で $2 \mathrm{kN}$ 程度となり，ま た横方向鉄筋にも引張力が生じていることから, 図 17-(d)のよう にアンカーボルト頭部と鉄筋の折り曲げ位置近傍の間でストラット を形成して引抜き力に抵抗したと考えられる，この効果によって， 横方向鉄筋を近傍に配置した $4 \mathrm{H} 30$ では，無配筋の試験体に対して わずかに耐力が大きくなったと推察できる.

\section{4. 2 縱方向鉄筋の影響}

アンカーボルト周辺に縦方向鉄筋を配筋した 4V30，4HV30 の最 大耐力時までの，縦方向鉄筋に生じた軸力の総和と引抜き荷重の推 移を図 18-(a)，（b)に示す．4HV30 については，アンカーボルト近 傍に配筋した縦方向鉄筋群 (鉄筋群 1) と，遠方に配筋した縦方向鉄 筋群 (鉄筋群 2) に生じた軸力の総和についてもそれぞれ示す。軸 カはコンクリート母材上面から $90 \mathrm{~mm}$ の位置に貼付した歪みゲー ジから算出した。横軸は抜け出し変位。るである。 また, 図中には 先述した短期許容荷重とコーン状破壊耐力の計算値についても併せ て示している４HV30 では，遠方にある縦方向鉄筋群に生じた軸 力の総和は最大耐力時にも, アンカーボルト近傍の鉄筇群に生じた 軸力の総和に対して $20 \%$ 程度であり, 遠方の鉄筋群の引抜き力に 対する抵抗は近傍の鉄筋群に対して小さいことが確認できる. 4V30，4HV30 の短期許容荷重下における縦方向鉄筋に生じた軸力 の総和は，引抜き荷重に対してそれぞれ $4.2 \% ， 3.7 \%$ ありり，また， コーン状破壊耐力の計算值にあたる荷重下においてもそれぞれ 8\%，6.7\%であり，コーン状破壊耐力の計算值にあたる荷重下まで の縦方向鉄筋の引抜き抵抗に対する寄与は小さい。一方，最大耐力 時ではそれぞれ $23 \% ， 46 \%$ に達しており，この結果とアンカーボル

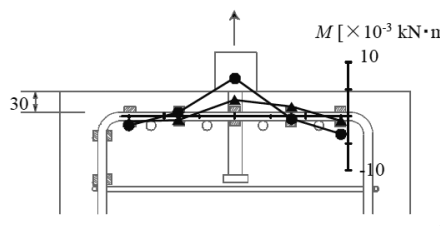

曲げモーメント $M$ 分布

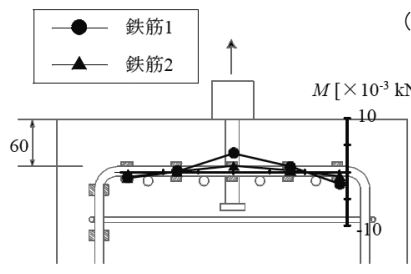

曲げモーメント $M$ 分布

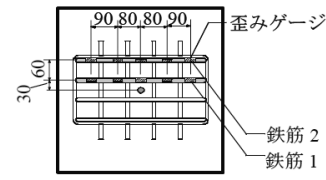

(c) ゲージ貼付位置

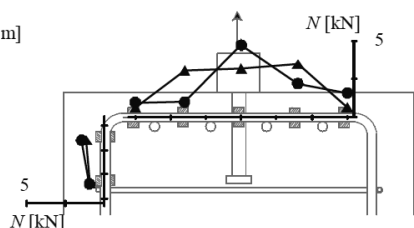

軸力 $N$ 分布

(a) $4 \mathrm{H} 30$

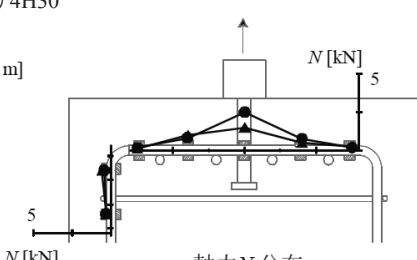

軸力 $N$ 分布

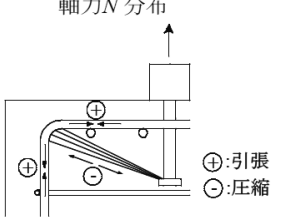

(d) 抵抗機構の模式図
図17横方向鉄筋に生じた軸力と曲げモーメントの分布
卜周辺に縦方向鉄筋を配筋した試験体がいずれも最大耐力が上昇し ていたことから，アンカーボルト周辺の縦方向鉄筋の存在はコーン 状破壊耐力の上昇に大きく寄与することがわかる．実験結果では， 2HV30 の試験体を除くアンカーボルト周辺に縦方向鉄筋を配筋し た試験体では，縦方向鉄筋の引抜き力に対する顕著な抵抗がみられ たことで, 最終的にアンカーボルトの破断によって最大耐力に至っ たため, コーン状破壊耐力への縦方向鉄筋の寄与に対して一般的な 評価を与えるには，さらなる実験が必要となる。ただし，本実験の 結果でわかるように, 無筋試験体の最大耐力はコーン状破壊耐力の 計算值により概ね評価できており，縦方向鉄筋を配した試験体につ いても, 引抜き荷重 $P_{v}$ 一抜け出し変位。 $\delta$ 関係においてコーン状破 壞耐力計算值以降にコンクリートの損傷に伴う非線形化が見られ る. 一方，歪ゲージより求めた縦方向鉄筋の軸力負担の推移を見る と, 引抜き荷重 $P_{v}$ 一抜け出し変位。 $\delta$ 関係において非線形化が見ら れるまでは軸力負担が小さいことが分かる．このことから, 本実験 の範囲では縦方向鉄筋の寄与はコンクリートの損傷が大きく進展し た後に得られるものであると言える. 免震構造では基礎構造との接 合部において高い剛性を維持し続ける必要があることから, アンカ 一ボルトの引抜き力に対する設計として, 縦方向鉄筋の寄与をあら かじめ期待することは望ましくないと言える.

\section{4. コーン状破壊耐力と有効水平投影半径の考察}

実験で観察された破壊面が設計で想定されている破壊面に比べ, 大幅に緩やかであるにもかかわらず，実験結果が 45 度の破壊面を 仮定した設計式によって概补評価できていた。ここではコンクリー 卜の破壊条件を仮定し, 最大耐力と有効水平投影半径について考察 する. 実際のコンクリート破壊面の断面積に引張割裂強度を乗じて 求めた引張力は実験時の最大耐力を大きく上回ることから，ここで の有効水平投影半径とは，コンクリート母材のひび割れ伝播がはじ

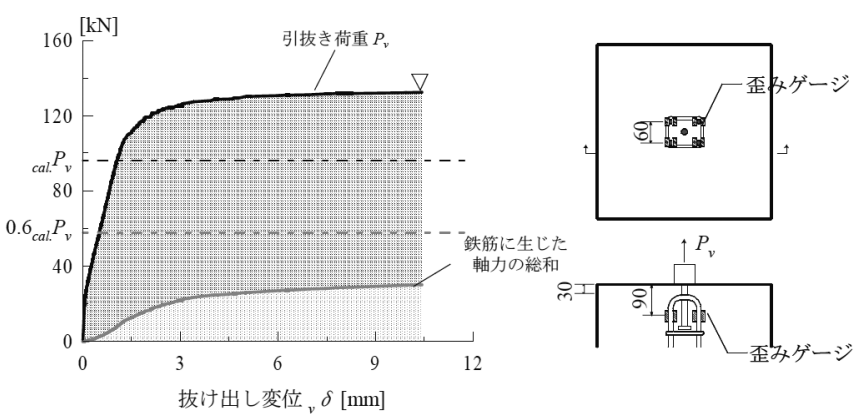

(a) $4 \mathrm{~V} 30$

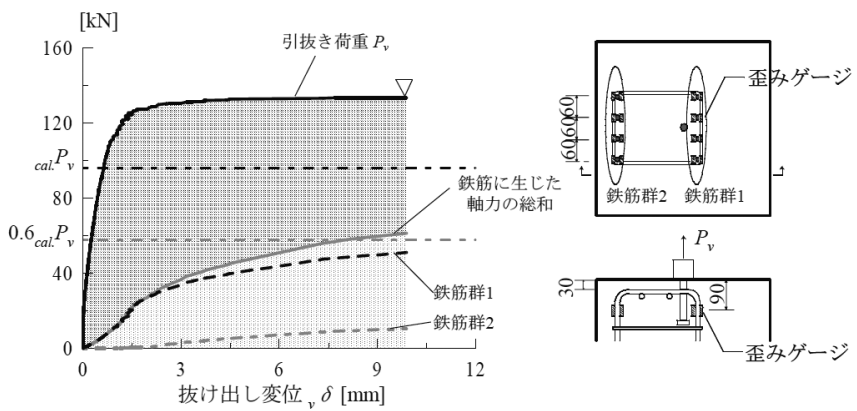

(b) 4 HV 30

図18 縦方向鉄筋に生じた軸力の推移 
まり破壊に至るまでの見かけの水平投影面積であると考えた。すな わち, 最大耐力に達した際には図 19 に示寸ように, 破壊面のある 範囲のコンクリートのみが引抜き力に抵抗したと仮定する。この範 囲内の有効水平投影半径を $\beta l_{e}$ とする. また, 破壊時には破壊面と 直交する方向に最大主応力が生じたものとし, 最大主応力が材料試 験によって得られた引張割裂強度 $f_{t}$ に達したときに破壊が生じるも のとする，さらに破壊面は軸対称であり，破壊時の破壞面内の応力 状態を等分布と仮定すれば，コーン状破壊耐力 ${ }_{0} P_{u}$ は式（2）で表 される。

$$
\begin{aligned}
& { }_{c} P_{u}=2 \pi \int_{D / 2}^{\beta l_{e}+D / 2}\left(f_{t} \cos \theta\right) \cdot \frac{r}{\cos \theta} d r \\
& =f_{t} \pi \cdot l_{e}\left(\beta \cdot l_{e}+D\right)
\end{aligned}
$$

式(2)では破壊面角度によらず，破壊耐力 ${ } P_{u}$ は抵抗している有効 水平投影面積とコンクリートの引張強度によって決まる. Nシリー ズと R シリーズの無筋試験体のコーン状破壊耐力の実験值より逆 算して求めた $\beta$ を表5に示寸. なお, 式(2) のコンクリートの引張 割裂強度 $f_{t}$ を $0.31 \sqrt{\sigma_{B}}$ に置き換え, 有効水平投影半径を $1.0 l_{e}$ と置けば現行の設計式である式(1) と一致する。本実験結果より逆 算した有効水平投影半径は $0.81 l_{e} \sim 0.96 l_{e}$ であり，現行の設計式に おいて 45 度方向と仮定している破壊面の有効水平投影半径 $1.0 l_{e}$ と ほぼ一致するものとなっている。本実験で観察されたコーン状破壊 面角度が緩やかであったにもかかわらず，実験結果と設計式によっ て算出した計算值が良好に対応したことがこの破壊モデルより説明 できると言える。ただし，本実験ではアンカーボルトの埋込み長さ が 90 120mm と比較的短いものとなっており, さらに長いアンカ 一ボルトを用いる場合では，45 度の破壊面を仮定した式（1）では 破壊耐力を過大評価するとの報告がある ${ }^{6,11)}$. 本研究の考察では, コーン状破壊耐力を求める上では破壊面角度に依らずコンクリート の引張抵抗領域を求めることが重要であることを示した，長いアン カーボルトを用いる際にもこのコンクリートが引張力に抵抗できる 領域がほとんど変わらないとすれば, 式（1）による計算值がコー ン状破壊耐力を過大評価寸ることを説明できる，近年，序文で述心 た免震部材接合用アンカーボルトの施工性による影響が問題視さ れ，長いアンカーボルトを用いる例が増えてきているが，これらの 耐力評価に従来のコーン状破壊耐力評価式が適用できるかは確認で きていない.ここで示したアンカーボルトの抵抗メカニズムの検証 や，長いアンカーボルトの耐力評価は今後の課題である.

\section{5. 結}

鉛ダンパー接合用アンカーボルトの引抜き挙動へ与えるアンカー ボルトの形状と，アンカーボルト周辺の鉄筋の影響を把握するため に， $\mathrm{N} ， \mathrm{R}$ シリーズの 2 種類の引抜き実験を行った。それぞれの実 験シリーズによって得られた結果を以下にまとめる。 また, 両シリ ーズに共通する結果と, その実験結果に基づきコーン状破壊耐力に 関する考察を行い，得られた結果についても以下に示す.

\section{【Nシリーズ(アンカーボルトの形状による影響)】}

1) 長ナット形式アンカーボルトでは, 長ナット被覆長さとねじ部 の付着長さが抜け出し性状に大きく影響した。本実験で用いたアン

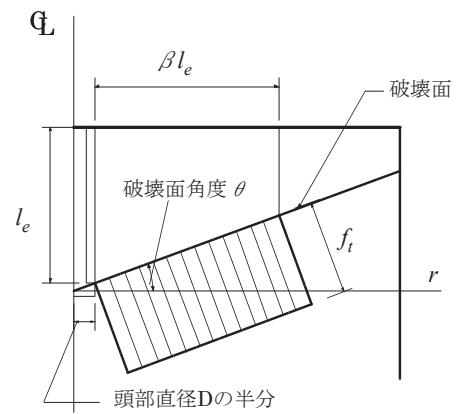

表 5 各試験体の $\beta$

\begin{tabular}{c|c}
\hline 試験体名 & $\beta$ \\
\hline S90 & 0.96 \\
\hline S120 & 0.91 \\
\hline N120 & 0.82 \\
\hline N120(50) & 0.81 \\
\hline N120(50)UB & 0.84 \\
\hline N120(80) & 0.86 \\
\hline N120(80)UB & 0.82 \\
\hline
\end{tabular}

図19 破壊面における応力分布の仮定

カーボルトの埋込み長さ $(120 \mathrm{~mm})$ では，その $80 \%$ 程度が長ナット によって被覆され，露出している部分が少なくなると頭部での支圧 抵抗が十分に行われず，破壊モードがスリップ破壊となり耐力が低 下した.

\section{【Rシリーズ (アンカーボルト周辺の鉄筋の影響)】}

2) アンカーボルト周辺に配筋した横方向鉄筋は, 引抜き耐力, 剛 性への寄与はみられない。

3）アンカーボルト周辺に縦方向鉄筋を配筋した試験体では，最大 耐力時に引抜き荷重に対して縦方向鉄筋に生じた軸力の総和が，20 \%以上に達していることから,引抜き抵抗に対する寄与が認められ， その結果，引抜き耐力は上昇した。 しかしながら，コーン状破壊耐 力の計算值に相当する荷重下では, 引抜き荷重に対して 7〜8\%程 度に留まり, 縦方向鉄筋の引き抜き抵抗への寄与は, コンクリート の損傷が大きく進展した後に得られるものである.

\section{【両シリーズ】}

4) アンカーボルトの長さ, アンカー形式の違い, 鉄筋の影響によ らず，破壞面は，設計で想定されるコーン破壊面より緩やかなもの となった。

5）破壊条件と応力分布を仮定した破壊モデルから，コーン状破壊 面の有効水平投影面積の半径について検討を行った。埋込み長さが 比較的短いアンカーボルトを使用した本実験の範囲では，埋込み 長さ $l_{e}$ の 0.81 0.96 倍として評価でき, 現行の設計式で想定する有効 水平投影半径と良い対応を示寸.

実験結果では，試験体の耐力・剛性に極端な差異はみられなかっ たが，実際には免震部材が据え付けられる立上部にコンクリートの 打ち継ぎ部が設けられるため, 打ち継ぎ部の応力伝達を行う上でも 鉄筋の配筋には十分な配慮が必要であると言える. 本実験で得られ た結果では，アンカーボルト近傍に配筋した縦方向鉄筋はコーン状 破壊耐力の上昇に寄与したが，アンカーボルトに直交する横方向鉄 筋は引抜き力に対する抵抗はほとんどなく，耐力への寄与は少なか った. むしろ横方向鉄筋の被り厚がアンカーボルトの埋込み長さと 近くなる場合は，鉄筋がコーン状破壊を助長するように働き，耐力 低下の要因となった可能性が高い。したがって, 本実験より得られ た知見によれば, 応力の厳しいアンカーボルトに対してはその周辺 に縦方向鉄筋を配筋しておくことが望ましいと言える.

謝辞

本研究は, 財団法人日本建築センターと社団法人日本免震構造協 会の補助を受け行いました。ここに記して謝意を表します。 


\section{参考文献}

1) 高山 峯夫, 森田 慶子, 柏木 栄介, 安藤 勝利 : 免震用鉛ダンパーの取 り付け部に作用する軸力と曲げモーメントに関する研究, その 1 , 2, 日 本建築学会大会学術講演梗概集, B-2 分冊, pp617-620, 2004. 9

2) 日本建築学会 : 各種合成構造設計指針・同解説 1985

3）松森 泰典, 河村 博之, 佐治 康次 : コンクリートに定着された鉄筋の 引抜き強度に関する研究（コンクリートが破壊する場合），九州大学工 学集報，第 44 巻第 6 号, pp747-754, 1971. 6

4) 白阪靖人, 松崎 育弘, 阿部 保彦, 宇佐美 滋: 機器配管用支持構造 物（埋込金物）の耐力に関する実験研究 その 1 コンクリートに埋め込 まれたスタッドボルトの引抜き耐力, 日本建築学会大会学術講演梗概集, 構造系分冊, pp1375-1376, 1979.9

5) Klingner, R., and Mendonca., J. : Tensile Capacity of Short Anchor Bolts and Welded Studs: Literature Review ACI JOURNAL, Vol.79, No.4, pp270-279, 1982
6) Fuchs, W., Eligehausen, R., and Breen, J. E. : Concrete Capacity Design (CCD) Approach for Fastening to Concrete, ACI STRUCTURAL JOURNAL, V.92, No.1, pp73-94, 1995

7) 近藤 吾郎, 森田 司郎：引抜き力を受けるアンカーボルトの応力伝達機 構の解析, 日本建築学会構造系論文報告集, No. 435, pp141-150, 1992, 5

8) 広瀬 景一, 小沢 宣行, 吉田 守, 山田哲, 坂田弘安, 和田 章: 免 震装置基礎躯体定着アンカー引張試験 その 1 , その 2 , 日本建築学会 大会学術講演梗概集, B-2 分冊, pp471-474, 2004. 9

9) 浅田 勇人, 都筑 碧, 吉敷 祥一, 和田 章 : 鉛ダンパー接合用アンカー ボルトの引抜き挙動に関する実験研究 その 1 , その 2 , 日本建築学会 大会学術講演梗概集, C-2 分冊, pp297-300, 2008. 8

10）免震構造協会 : JSSI 免震構造施行標準 2005

11) Lee, N., Kim, K., Bang, C., and Park, K. : Tensile-Headed Anchors with Large Diameter and Deep Embedment in Concrete, ACI STRUCTURAL JOURNAL, V.104, No.4, pp479-486, 2007 